\title{
WATER DEFICIENCY ON THE MAIZE GRAIN YIELD DECREASE IN THE CATARINENSE FAR WEST
}

\author{
CLÍSTENES ANTÔNIO GUADAGNIN ${ }^{1}$, EDGAR RICARDO SCHÖFFEL ${ }^{2}$, \\ HÉLVIO DEBLI CASALINHO² and IVAN LUIZ ZILLI BACIC ${ }^{1}$
}

${ }^{1}$ Empresa de Pesquisa Agropecuária e Extensão Rural de Santa Catarina,agroguada@gmail.com, bacic@epagri.sc.gov.br ${ }^{2}$ Universidade Federal de Pelotas (UFPel), ricardo.schoffel@gmail.com,hdc1049@gmail.com

Revista Brasileira de Milho e Sorgo, v.16, n.1, p. 61-71, 2017

\begin{abstract}
Maize is of fundamental social economical importance for familiar agriculture in the west of the State of Santa Catarina. In this region, the decrease of grain yield of the culture is frequently related to periods of water deficiency. The purposes of the present study were to assess the maize grain yield decrease due to water deficiency, identify the sowing time with a lower risk of water deficiency and determine and probability of risks of grain yield decrease. The grain yield decrease was calculated using the Isareg model, based on the ten-day water balance, for the period between1989/90 to 2010/11, simulated for nineteen sowing dates and three cycles of maize maturation. The model estimated an average grain yield decrease of $25.1 \%$. The biggest decrease took place in the initial sowing of August and the smallest in the late sowings between January and February, with a maximum variation of 3.9\% between the assessed maturation cycles. The Isareg model is appropriate to estimate the grain yield decrease, however it overestimates its value when the relative evapotranspiration is above 0.8 . The levels of $40 \%$ of grain yield decrease present $10.5 \%$ of probability of occurrence.
\end{abstract}

Keywords: drought, hydric balance, simulation model, sowing time, crop yield losses.

\section{DEFICIÊNCIA HÍDRICA NA REDUÇÃO DE PRODUTIVIDADE DO MILHO NO OESTE CATARINENSE}

RESUMO - O milho é de fundamental importância socioeconômica para a agricultura familiar da região do Extremo Oeste Catarinense. Nessa região, a redução da produtividade da cultura está frequentemente relacionada aos períodos de deficiência hídrica. Os objetivos deste estudo foram avaliar a redução de produtividade de milho devido à deficiência hídrica, identificar as épocas de semeadura com menor risco de deficiência hídrica e determinar a probabilidade de riscos de redução de produtividade. A redução de produtividade foi calculada pelo modelo Isareg, baseado no balanço hídrico decendial, para o período 1989/90 a 2010/11, simuladas para dezenove datas de semeadura e três ciclos de maturação de milho. O modelo estimou uma redução de produtividade média de $25,1 \%$. A maior redução ocorreu na semeadura inicial de agosto e a menor nas semeaduras tardias entre janeiro e fevereiro, com variação máxima de $3,9 \%$ entre os ciclos de maturação avaliados. O modelo Isareg é apropriado para estimar a redução de produtividade, entretanto superestima seu valor quando a razão entre evapotranspiração real e evapotranspiração da cultura for maior que 0,8 . Os níveis de $40 \%$ de redução de produtividade apresentam 10,5\% de probabilidade de ocorrência.

Palavras-chave: estiagem, balanço hídrico, modelo de simulação, épocas de semeadura, perda de rendimento. 
Maize is the main component of the productive chain of swine and poultry in Santa Catarina. The west of the State of Santa Catarina, characterized by familiar agriculture, presented in the harvest of 2012/2013 the third highest area planted with maize (59.1 thousand ha) in the state, with an average grain yield of $6.626 \mathrm{~kg} \mathrm{ha}^{-1}$ (Epagri, 2013). However, this region is the most affected by droughts, with the occurrence of water deficiency mainly during three months of the year (January, July and December), usually associated to the La Niña phenomenon, causing considerable variations in the maize production (Epagri, 2013).

The water availability is considered one of the most important factors to express the potential of the maize culture production in the South of Brazil (Massignam, 2005; Wagner et al., 2013). The impact resulting from the water deficiency in the maize culture provokes its grain yield decrease, which has as an important variable the relative evapotranspiration defined when the real growth evapotranspiration (ETr) is smaller than the culture evapotranspiration (ETc), determining the risk of grain yield decrease of the culture (Nied et al., 2005; Cancela et al., 2006).

The estimate of grain yield decrease in the maize culture is important for planning and decisionmarking from the farms to state level. One way to measure these losses due to water deficiency has been through computer simulation (Massignam, 2005). Isareg is a software of simulation model of hydric balance, easily parameterized, which demands the essential soil hydraulic characterization, weather data and basic parameters of the culture, besides adopting simplified functions from the relation water-yield to assess the effects of water deficiency in the grain yield decreases (Teixeira \& Pereira, 1992; Cancela et al., 2006). Several studies (Victoria et al., 2005;
Popova \& Pereira, 2011; Chaterlán et al., 2012; Saraiva et al., 2013) used the Isareg model due to a lower requirement of input data concerning the soil and agronomic parameters, the employment of simple procedures to estimate the grain yield decreases, besides presenting good results for different cultures and soil and climate conditions.

Considering the soil and climate characteristics in the west of the State of Santa Catarinathe present work aims to assess the impact of water deficiency in the maize grain yield decrease for different maturation cycles (early, normal and late), identify the sowing time with the lowest risk of maize grain yield decrease because of water deficiency, test the Isareg model for the estimate of grain yield decrease and estimate the probability of grain yield decrease resulting from water deficiency.

\section{Material and Methods}

The study was carried out in the west of the State of Santa Catarina, Brazil, involving 21 counties belonging to the region of São Miguel do Oeste. This region presents two climate types: humid subtropical with hot summer (Cfa) and humid subtropical climate with mild summer ( $\mathrm{Cfb}$ ), according to Köppen classification. The annual average temperature in this region is $19.3^{\circ} \mathrm{C}$, in which the average temperature in the coldest month is $14.2^{\circ} \mathrm{C}$ and in the hottest month it is $25.3^{\circ} \mathrm{C}$, with a monthly average sunshine of 177 $\mathrm{h}$. The annual average rainfall ranges from 1.430 to $2.280 \mathrm{~mm}$, with an annual of rainy days between 118 and 146 days (Epagri, 2013). The meteorological variables with daily data concerning air temperature, relative humidity of the air, rainfall, sun radiation and wind speed were obtained in the representative historical series for the region, for the period of 25 
years (1987 to 2011), from the São Miguel do Oeste station (26 47'05'S, 53'30'13' $\mathrm{W}$ and $700 \mathrm{~m}$ ), belonging to EPAGRI/CIRAM.

The Isareg model (Teixeira \& Pereira, 1992) was used to calculate the water balance, in a tenday scale, and estimate the grain yield decrease in the maize culture. The model validation was carried out according to what was described in Guadagnin et al. (2012), through the grain yield decrease values estimated by the model, compared with data from the historical series of maize average grain yield for the west of the State of Santa Catarina, between the agricultural years of $1989 / 90$ to $2010 / 11$, provided by IBGE (IBGE, 2012). The Isareg model input variables are the following: field capacity, permanent withering point, soil samples layer depths, beginning dates of the phenologic phases of the maize culture (Table 1), "p" factor " $p$ " of water availability in the soil, root system depth, crop coefficient, total of rainfall and reference evapotranspiration calculated by the PenmanMonteith/FAO methodology followed by Araújo et al. (2007) and Sousa et al. (2010). Phenological phases of culture considered: sowing, beginning of vegetative growth, flowering start, beginning of fruit formation, physiological maturation onset and harvest. The simulations were carried out individually for each year of the 22 years of the historical series considered integrated with each of the 19 sowing dates, for each of the 3 groups of maize physiological maturation (in days until harvest): early group (110 days), normal group (130 days) late group (150 days).

The edaphic parameters were obtained by collecting 12 soil samples in the de $0-0.10,0.10$ $0.20,0.20-0.40$ and $0.40-0.60 \mathrm{~m}$ layers, according to the methodology used by Kaufmann et al. (2014). Only the soil predominant classes in the region were considered. Were considered basically Cambisol soils, in which the selection of soils collection places was based on information of the Epagri Rural Extension technicians, who identified farms with the predominant soil characteristics and direct sowing system from the region.

To apply the Isareg model, concerning agronomic parameters, 19 maize sowing time were considered for the early, normal and late maturation cycles, apart every 10 days, from August $12^{\text {th }}$ to February 08th, a recommendation period from the Ministry of Agriculture Climate Risk Agricultural Zoning (Brasil, 2012), for the Far West region counties. The estimate of the beginning days of each maize phenologic phase was defined based on degrees day. The crop coefficients $(\mathrm{Kc})$ and the water

Table 1. Input parameters for Isareg model simulations for each agricultural year and for different maize sowing time, in the period between 1990-2011 in the west of the State of Santa Catarina.

\begin{tabular}{|c|c|c|c|c|c|c|}
\hline \multirow[b]{2}{*}{ Phenological Phases of Culture } & \multirow[b]{2}{*}{$\mathrm{Kc}$} & \multirow[b]{2}{*}{ Ky } & \multirow{2}{*}{$\begin{array}{c}\text { Factor } p \\
(\%)\end{array}$} & \multicolumn{3}{|c|}{ Number of days until harvest } \\
\hline & & & & $\begin{array}{l}\text { Early } \\
\text { Group }\end{array}$ & $\begin{array}{l}\text { Normal } \\
\text { Group }\end{array}$ & $\begin{array}{l}\text { Late } \\
\text { Group }\end{array}$ \\
\hline A- Sowing & 0,1 & 1,15 & 100 & 0 & 0 & 0 \\
\hline B- Beginning of vegetative growth & 0,3 & 1,15 & 70 & 30 & 35 & 40 \\
\hline C- Flowering start & 0,8 & 1,15 & 70 & 60 & 70 & 80 \\
\hline D- Beginning of fruit formation & 1,2 & 1,15 & 70 & 80 & 90 & 100 \\
\hline E- Physiological maturation onset & 1,2 & 1,15 & 70 & 110 & 130 & 150 \\
\hline F- Harvest & 0,9 & 1,15 & 70 & 131 & 151 & 171 \\
\hline
\end{tabular}


availability factor in the soil (p) are described in Doorenbos and Kassam (1979).

The identification of sowing period less subject to water deficiencies harmful to the maize was assessed through estimate of grain yield decrease, according to Stewart's monophase model modified by Doorenbos and Kassam (1979) expressed by a linear relationship between the production deficit and the evapotranspiration deficit through the equation:

$$
1-\frac{Y_{a}}{Y_{m}}=k y\left(1-\frac{E T r}{E T c}\right)
$$

In which: $Y_{a}$ is the real culture grain yield obtained from the official data set of maize agricultural production according to IBGE (IBGE, 2012), $Y_{m}$ is its maximum grain yield, ETr is the culture real evapotranspiration, ETc is the culture evapotranspiration and $\mathrm{ky}$ is the culture response factor to the water deficiency, also called water sensitivity coefficient. The maximum grain yield of maize $\left(\mathrm{Y}_{\mathrm{m}}\right)$ was adjusted so that the simulations with the Isareg model determined that during the whole crop cycle it would remain under the comfort of the water, with the supply of its evapotranspirative demand to seek the maximization of the grain yield potential of the crop. The relation ETr ETc ${ }^{-1}$, defined as relative evapotranspiration, was obtained by using a ten-day water balance. The $k y$ value was kept constant (1.15) for the whole culture cycle, according to the Isareg model parameterization.

The grain yield decrease based on data from the Brazilian Institute for Geography and Statistics (IBGE) was calculated using the statistical analysis (Anova) with the use of spreadsheets. The probabilities of grain yield decrease were determined in the highest frequencies on the levels of 10, 25 and $40 \%$ of grain yield decrease, levels also studied by Nied et al. (2005). The probabilities were calculated through the gamma function $(\gamma)$, which enabled a better adjustment of the parameters for each of the 19 series of simulated sowing time. The adhesion of the probabilities for the estimated frequencies was checked using the Qui-square testin a 5\% level of significance.

\section{Results and Discussion}

The analysis between the grain yield decrease estimated based on data from the IBGE and the mean ratio $\mathrm{ETr}_{\mathrm{ETc}}^{-1}$ (Figure 1) indicates that $83.3 \%$ of the relative evapotranspiration values $\left(\mathrm{ETr} \mathrm{ETc}^{-1}\right)$ were highest than 0.7 and qualified as low risk ones, while the other results present ratings between 0.6 and 0.7 considered as medium risk, according to the classification proposed by Matzenauer et al. (2002).

The low risk of severe water deficiency able to cause high grain yield decreases was also noticed, considering as limit the critical value lower than 0.6 for the ratio ETr Eto ${ }^{-1}$ admitted by Leivas et al. (2006). An agreement of these results was observed in relation to sowing time recommended by the rules of agricultural zoning of climate risk for the maize culture in the Santa Catarina State, rating as eligible the counties which presented in at least $20 \%$ of their territory a relative evapotranspiration $\left(\mathrm{ETr} \mathrm{ETc}^{-1}\right)$ highest or similar to 0.55 with a frequency of $80 \%$ in the assessed years and a risk of occurrence of frost similar to 20\% (Brasil, 2012).

The non-linearity between the relative evapotranspiration and the grain yield decrease based on data from the IBGE characterized a limitation of the Isareg model, which overestimated the grain yield decrease when the relative evapotranspiration was highest than 0.8 . Above this value of the relative evapotranspiration there was a low risk of grain 


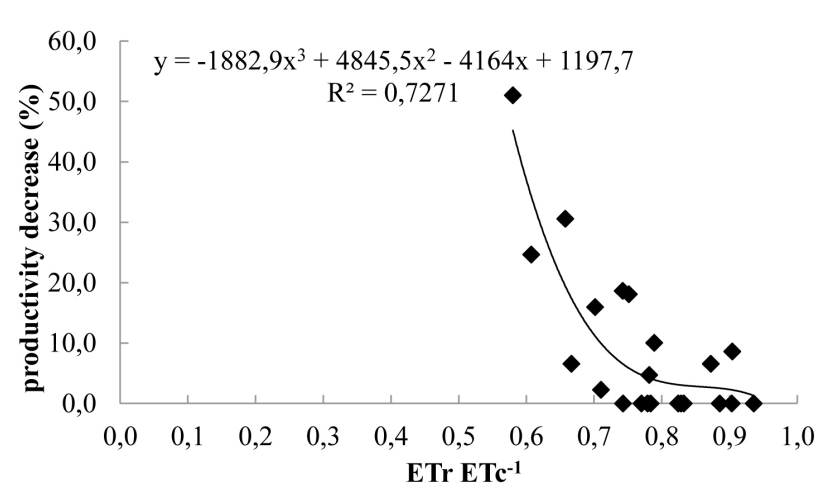

Figure 1. Maize grain yield decrease and the mean ratio of the real (ETr) and the culture evapotranspirations (ETc), in the period of 1990-2011, in the west of the State of Santa Catarina. The ETr ETc ${ }^{-1}$ values are averages of the 19 sowing time and of three maize maturation cycles in Cambisol soil under direct sowing.

yield decrease based on data from the IBGE, with all values lower than $10 \%$. According to Bergamaschi et al. (2006), the stabilization of maize yield with low water deficiency or high relative evapotranspiration, which characterize a low risk situation, it occurs next to a relative evapotranspiration $\left(\mathrm{ETr}_{\mathrm{ETc}}{ }^{-1}\right)$ similar or highest than 0.7 and, when lower than this value, it explains almost $80 \%$ of the maize grain yield variations.

The absence of linearity noticed when the ratio $\mathrm{ETr} \mathrm{ETc}^{-1}$ was higher than 0.8 can be related to the maintenance of constant value of ky in 1.15. This parameterization may represent a performance limitation of the model as it does not permit the introduction of $k y$ values for the different maize phonological phases. According to Doorenbos and Kassam (1979), the sensibility of the maize culture to the water supply is rated as medium/high, with ky values between 1.00 to 1.15 because the ky factor > 1.0 indicates that the intensity of grain yield decrease is proportionally highest in relation to the increase of water deficiency.
Although the results point out to highest frequency of low risk of water deficiency, the occurrence of relative evapotranspiration lower than 0.7 indicates the possibility of water deficiency which may set high grain yield decreases (Figure 1). Massignam (2005) found that the lower values of ETr $\mathrm{ETc}^{-1}$, when matching periods of high atmospheric evaporative demand and large rain variability, set the highest grain yield decreases in the Catarinense Midwest region.

In experimental conditions, Cancela et al. (2006) warn about the difficulty to adjust the mean losses of maize relative yield, estimated with the Isareg model, with the respective experimental data, once experimental results do not cover the demand conditions for the dry and the very dry years. However, as it can be seen in the Figure 2, the correlation between the grain yield decrease estimates based on data from the IBGE presented a satisfactory degree of dependence of approximately $70 \%$ of the annual variations of grain yield decrease estimated by the Isareg model. Thus, the Isareg model was able to estimate the grain yield decrease due to water deficiency in the maize harvest when compared to IBGE data, despite the limitations noticed when the relative evapotranspiration presented values highest than 0.8 indicating that the model was less efficient to estimate the grain yield decrease.

The grain yield decrease of the maize culture due to water deficiency, estimated by the Isareg model, in the west of the State of Santa Catarina presented an average value of $25.1 \%$ between the different periods, maturation cycles and harvests in the period between 1990-2011, in the west of the State of Santa Catarina (Figure 3). However, there was a small variation of the culture grain yield decrease between the sowing time and between the maturation cycles (average of up to $3.9 \%$ ). 


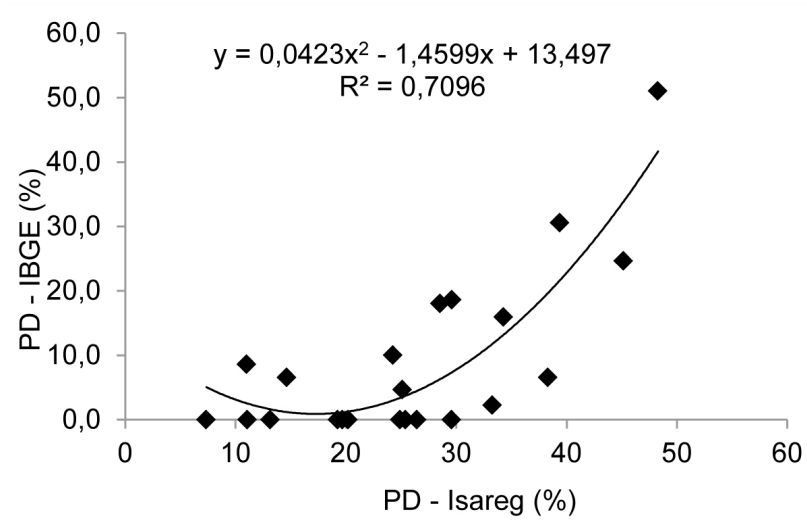

Figure 2. Maize grain yield decrease based on IBGE data (PD - IBGE) and the corresponding grain yield decrease estimated by the Isareg model (PD - Isareg) for the period of 1990-2011, in the west of the State of Santa Catarina.

The reductions in grain yield presented a trend of decrease from the initial sowing period (August) in relation to late sowing time (January-February), regardless the maturation cycle (Figure 3). These results match the ones found by Massignam (2005) for Campos Novos, in the Midwest of the Santa Catarina State, in which it has been noticed that the early maize sowings (August) presented a highest risk of water deficiency due to a longer sowing subperiod to the emergence because of low air temperatures, an increase of hazard risks due to frosts in the emergence subperiod - blooming, and low average solar radiation values which may cause a smaller biomass production resulting from lower rates of photosynthesis.

The trend observed about highest grain yield decreases during the early sowing time if compared to the late sowing time, despite the small variations (Figure 3), can be explained due to periods with highest risks of possible water deficiency occurring at the same time as the culture critical subperiods. In this sense, Nied et al. (2005), in researches carried out in the central region of Rio Grande do Sul, found out that the highest risks of water deficiency associated to high temperatures occurred during the sowing period from October to the first half of November, as there

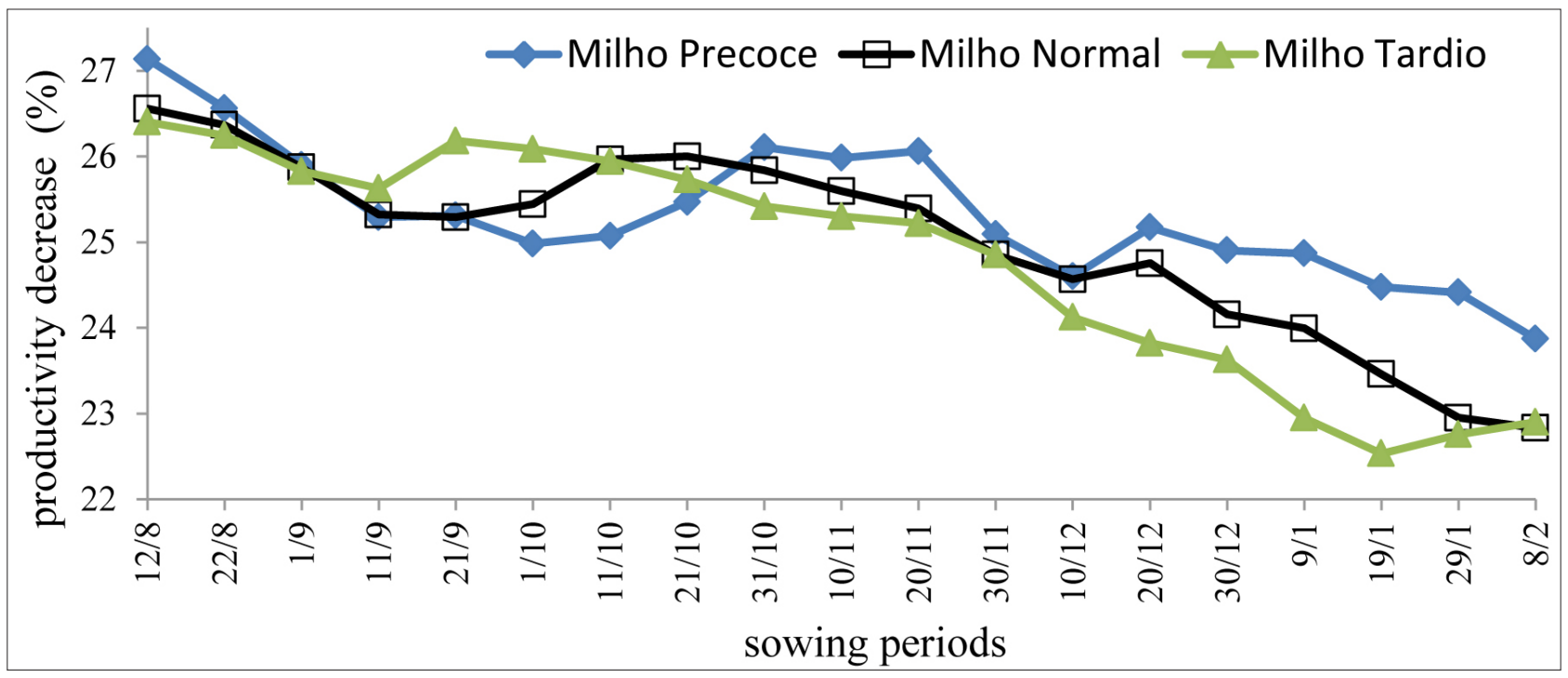

Figure 3. Maize culture average grain yield decrease estimated by the Isareg model for three maturation cycles based on 19 sowing time, in the period of 1990-2011, in the west of the State of Santa Catarina. 
is a highest probability that the events concerning the culture critical period and lower rainfall occurring together, which damages the pollination and reduces the number of grains by ear.

Small variations in the grain yield decrease between the three maturation cycles, of about $1 \%$, were observed for the maize sowings carried out until December $10^{\text {th }}$ (Figure 3). Differences of up to $10 \%$ of probability of highest water deficiency occurrence in the critical subperiod for three maize maturation groups were obtained by Nied et al. (2005), in the central region of Rio Grande do Sul. For Massignam (2005), the water deficiency did not interfere in the determination of the maize sowing period for Campos Novos, in the Catarinense Midwest.

Considering the small variations of grain yield decrease, due to the sowing time and between the maturation cycles (Figure 3), it can be inferred that the decision concerning the maize sowing period in the west of the State of Santa Catarina should not be limited only to the occurrence of periods with a highest probability of water deficiency, and the complexity of biotic and abiotic factors related to the different production systems must be considered, such as the characteristics of the farm, the maize cultivations, the farmer's technological level and the financial capital available.

For the 19 sowing time assessed in each agricultural year (1987 to 2011), the grain yield decrease estimated through the Isareg model ranged between 0.6 a $61.2 \%$ with an average value of $25.1 \%$ (Figure 4 ), in which in $8 \%$ of the years studied, there was a decrease above $40 \%$ in the maize grain yield.

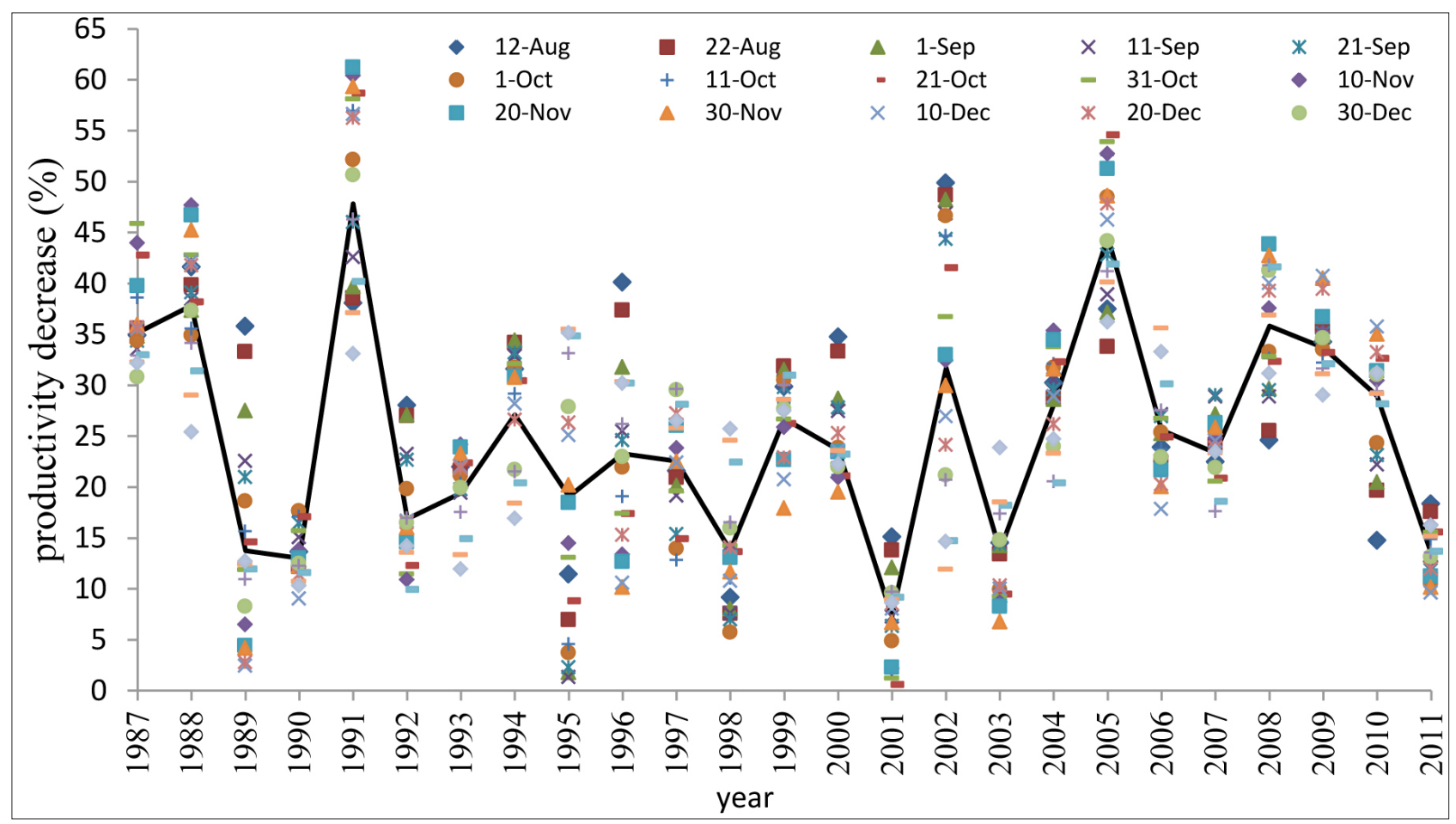

Figure 4. Average grain yield decrease estimated through the Isareg model for each agricultural year and for different maize sowing time, in the period between 1990-2011 in the west of the State of Santa Catarina. The productvity decrease was the average of the three maize maturation cycles. 
The results of grain yield decrease estimated by the Isareg model for 2005, one of the years with the highest grain yield decrease (35 to 52\%), were similar to the ones found by Massignam (2005) in counties in the Catarinense Midwest, with decrease values between 40 to $64 \%$ due to droughts in the 2004/2005 harvest which seriously affected the maize culture in several regions in the State of Santa Catarina.

The highest decreases in the maize average grain yield estimated by the Isareg model were observed in the years of 1991, 2002 and 2005 (Figure 4). It was noticed that the results of water deficiency found in those years correspond to the harvests in which there were decreases in the average productivities registered by IBGE (IBGE, 2012). However, the diversity of average values of grain yield decrease found between the years may reflect the complexity of factors comprise the variability of cultivation systems in several climate and soil conditions, phytosanitary conditions and production costs which are changed every harvest. Studies carried out in southern states in Brazil by Massignam (2005), Nied et al. (2005) and Bergamaschi et al. (2006) showed that the highest grain yield decreases due to water deficiency, are mainly associated to meteorological conditions noticed in period of high solar radiation, high temperatures and unequal distribution of rains.

The estimated probability of grain yield decrease with a risk highest than $50 \%$ harmful to the maize culture was of $2.6 \%$ (Figure 5). It has been observed that values of up to $5 \%$ of maize grain yield decrease corresponded to $98.2 \%$ of occurrence probability. It thus has been noticed, for the west of the State of Santa Catarina, that the severe grain yield decreases in the maize culture because of water deficiency presented a lower occurrence probability. In this region, it has been noticed on average of $10.5 \%$ of grain yield decrease probability in a $40 \%$ level,

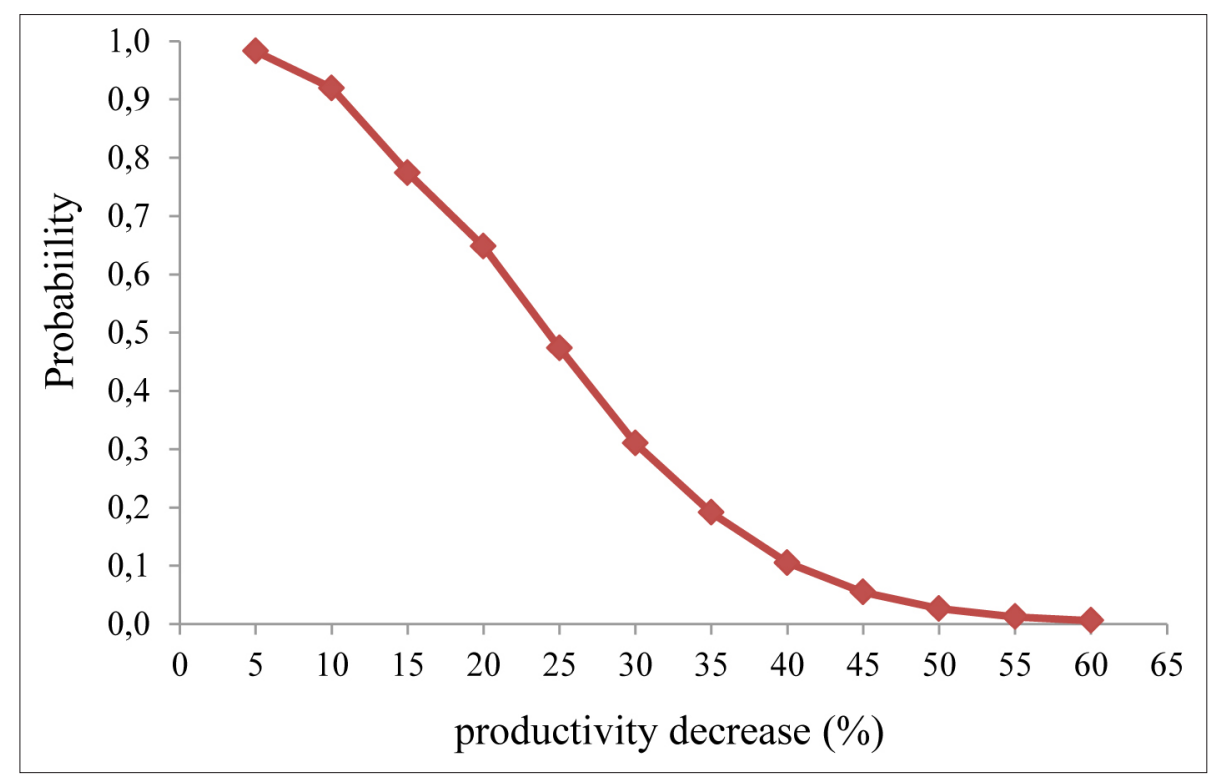

Figure 5. Estimated probability of grain yield decrease by the Isareg model for harvests of cultivated maize culture, in the period of 1990-2011 in the west of the State of Santa Catarina. Average date from 19 maize sowing time and three maturation cycles. 
similarly to what was found by Nied et al. (2005) in the central region of Rio Grande do Sul.

Regardless the maize sowing period and the maturation cycle, an average risk of $50 \%$ was determined concerning probability for the occurrence of grain yield decreases of up to $25.1 \%$ in the west of the State of Santa Catarina. In the late sowings carried out after the 2nd 10 days of February in the Catarinense Plateau, Cardoso and Soccol (2008) noticed the frequency of $50 \%$ of probability of null yields due mainly to the low temperatures, high risk of water deficiency and solar radiation reduction. Different from what has been found in this study, Wagner et al. (2013) observed that the average probability of maize grain yield decrease due to water deficiency is about $50 \%$, due to the water availability assessed in the Central region of Paraná.

The great variability of grain yield decreases in the west of the State of Santa Catarina was characterized mainly between the years assessed. Thus, it is recommended finding strategies to minimize the probability of high grain yield decreases, even when in low levels of occurrence. The strategy of distributing the sowing time through dispatching and the improvement of quality of soil through handling systems which promote an adequate storage of water represent significant contributions to reduce the risks of water deficiency along the harvests.

\section{Conclusions}

The grain yield decrease due to water deficiency presents an average value of $25.1 \%$, with small variation between the maize sowing time and the maturation cycles for the west of the State of Santa Catarina. The risk of grain yield decreases shows a downward trend from the initial sowing periods in relation to the simulated end periods. However, there was a great variability of grain yield decreases between the years. The Isareg model was able to estimate the grain yield decrease, but it overestimates the decrease values when the relative evapotranspiration is highest than 0.8 . For the maize cultivations in the spring/summer and summer/fall there is a $50 \%$ probability of the culture grain yield to be reduced in $25 \%$ in relation to the grain yield potential of the west of the State of Santa Catarina.

\section{References}

ARAÚJO, W. F.; COSTA, S. A. A.; SAnTOS, A. E. dos. Comparação entre métodos de estimativa da evapotranspiração de referência (ETo) para Boa Vista, RR. Revista Caatinga, Mossoró, v. 20, n. 4, p. 84-88, 2007.

BERGAMASCHI, H.; DALMAGO, G. A.; COMIRAN, F.; BERGONCI, J. I.; MÜLlER, A. G.; FRANÇA, S.; SANTOS, A. O.; RADIN, B.; BIANCHI, C. A. M.; PEREIRA, P. G. Déficit hídrico e produtividade na cultura do milho. Pesquisa Agropecuária Brasileira, Brasília, DF, v. 41, n. 2, p. 243-249, 2006.

DOI: $10.1590 / \mathrm{S} 0100-204 \mathrm{X} 2006000200008$.

BRASIL. Ministério da Agricultura, Pecuária e Abastecimento. Portarias de zoneamento agrícola de risco climático. Brasília, DF, 2012. Disponível em: $<$ http:// www.agricultura.gov.br/politica-agricola/zoneamentoagricola>. Acesso em: 15 out. 2013.

CANCELA, J. J.; CUESTA, T. S.; PEREIRA, L. S. Modelling for improved irrigation water management in a temperate region of Northern Spain. Biosystems Engineering, Oxford, v. 94, n. 1, p. 151-163, 2006. DOI: 10.1016/j.biosystemseng.2006.02.010.

CARDOSO, C. O.; SOCCOL, O. J. Corn performance with late sowing in Planalto Catarinense, Brazil, simulated with 
Ceres-maize model. Brazilian Archives of Biology and Technology, Curitiba, v. 51, n. 4, p. 455-464, ago. 2008. DOI: $10.1590 / \mathrm{S} 1516-89132008000400002$.

CHATERLÁN, Y.; HERNÁNDEZ, G.; LÓPEZ, T.; MARTÍNEZ, R.; PUIG, O.; PAREDES, P.; PEREIRA, L. S. Estimation of the papaya crop coefficients for improving irrigation water management in south of Havana. Acta Horticulturae, The Hague, v. 928, p. 179-186, 2012. DOI: 10.17660/ActaHortic.2012.928.21.

DOORENBOS, J.; KASSAM, A. H. Efectos del agua sobre el rendimiento de los cultivos. Roma: FAO, 1979. 212 p. (Estudio FAO. Riego y Drenaje, 33).

EPAGRI. Empresa de Pesquisa Agropecuária e Extensão Rural de Santa Catarina. Síntese Anual da Agricultura de Santa Catarina 2012-2013. Florianópolis, 2013. $180 \mathrm{p}$.

GUADAGNIN, C. A.; TIMM, L. C.; TAVARES, V. E. Q.; LOUZADA, J. A. S. Validação do modelo ISAREG para simulação do balanço hídrico em Cambissolos do extremo oeste de Santa Catarina. In: ENCONTRO DE PÓS-GRADUAÇÃO DA UFPEL, 14., 2012, Pelotas. Anais... Pelotas: Universidade Federal de Pelotas, 2012, p. 1-4.

IBGE. Sistema IBGE de Recuperação Automática - SIDRA: produção vegetal. Rio de Janeiro, 2012. Disponível em: <http://www.sidra.ibge.gov.br/bda/agric>. Acesso em: 11 out. 2012.

KAUFMANN, V.; PINHEIRO, A.; CASTRO, N. M. R. Simulating transport of nitrogen and phosphorus in a Cambisol after natural and simulated intense rainfall. Journal of Contaminant Hydrology, Amsterdam, v. 160, p. 53-64, 2014.

DOI: 10.1016/j.jconhyd.2014.02.005.

\section{LEIVAS, J. F.; BERLATO, M. A.; FONTANA, D. C. Risco} de deficiência hídrica decendial na metade sul do Estado do Rio Grande do Sul. Revista Brasileira de Engenharia Agrícola e Ambiental, Campina Grande, v. 10, n. 2, p. $397-$ 407, 2006. DOI: 10.1590/S1415-43662006000200022.
MASSIGNAM, A. M. Época de semeadura e o impacto da estiagem no rendimento da cultura do milho no meio oeste catarinense. In: CONGRESSO BRASILEIRO DE AGROMETEOROLOGIA, 14., 2005, Campinas. Agrometeorologia, agroclimatologia e agronegócio: anais. Campinas: Unicamp, 2005. 1 CD-ROM.

MATZENAUER, R.; BERLATO, M. A.; MALUF, J. R. T.; BARNI, N. A.; BUENO, A. C.; DIDONÉ, I. A.; ANJOS, C. S. dos; MACHADO, F. A.; SAMPAIO, M. dos R. Consumo de água e disponibilidade hídrica para milho e soja no Rio Grande do Sul. Porto Alegre: FEPAGRO, 2002. 105 p. (Boletim FEPAGRO, 10).

NIED, A. H.; HELDWEIN, A. B.; ESTEFANEL, V.; SILVA, J. C. da; ALBERTO, C. M. Épocas de semeadura do milho com menor risco de ocorrência de deficiência hídrica no município de Santa Maria, RS, Brasil. Ciência Rural, Santa Maria, v. 35, n. 5, p. 9951002, set./out. 2005.

DOI: $10.1590 / \mathrm{S} 0103-84782005000500003$.

POPOVA, Z.; PEREIRA, L. S. Modelling for maize irrigation scheduling using long term experimental data from Plovdiv region, Bulgaria. Agricultural Water Management, Amsterdam, v. 98, n. 4, p. 675-683, 2011. DOI: 10.1016/j.agwat.2010.11.009.

SARAIVA, K. R.; BEZERRA, F. M. L.; SOUZA, F. de; COMBOIM NETO, L. de F. Aplicação do "Isareg" no manejo da irrigação na cultura da melancia no Baixo Acaraú, Ceará. Revista Ciência Agronômica, Fortaleza, v. 44, n. 1, p. 53-60, 2013

SOUSA, I. F.; SILVA, V. P. R.; SABINO, F. G.; SILVA, B. K. N.; AZEVEDO, P. D. Evapotranspiração de referência nos perímetros irrigados do Estado de Sergipe. Revista Brasileira de Engenharia Agrícola e Ambiental, Campina Grande, v. 14, n. 6, p. 633-644, 2010.

DOI: $10.1590 / \mathrm{S} 1415-43662010000600010$.

TEIXEIRA, J. L.; PEREIRA, L. S. ISAREG: an irrigation scheduling model. ICID Bulletin, New Delhi, v. 41, n. 2, p. 29-48, 1992. 
VICTORIA, F. B.; VIEGAS FILHO, J. S.; PEREIRA, L. S.; TEIXEIRA, J. L.; LANNA, A. E. Multi-scale modeling for water resources planning and management in rural basins. Agricultural Water Management, Amsterdam, v. 77, n. 1/3, p. 4-20, 2005. DOI: 10.1016/j.agwat.2004.09.037.
WAGNER, M. V.; JADOSKI, S. O.; MAGGI, M. F.; SAITO, L. R.; LIMA, A. dos S. Estimativa da produtividade do milho em função da disponibilidade hídrica em Guarapuava, PR, Brasil. Revista Brasileira de Engenharia Agrícola e Ambiental, Campina Grande, v. 17, n. 2, p. 170-179, 2013. DOI: $10.1590 / \mathrm{S} 1415-43662013000200008$. 